\title{
Combination of Structural Data and GIS Tools in the Delineation of Groundwater Potential Zone in Crystalline Terrain: The Case of Southeastern Senegal
}

\author{
Ibrahima Mall ${ }^{1, *}$, Mahamadane Diène ${ }^{2}$, Moctar Diaw ${ }^{1}$, Papa Malick Ngom ${ }^{1}$, Serigne Faye ${ }^{1}$ \\ ${ }^{1}$ Department of Geology, Faculty of Sciences and Technique, Cheikh Anta DIOP University, Dakar, Senegal \\ ${ }^{2}$ Institut of Earth Sciences, Cheikh Anta DIOP University, Dakar, Senegal
}

Email address:

ibrahimamall@yahoo.fr(I. Mall),ibrahima.mall@ucad.edu.sn(I. Mall)

*Corresponding author

To cite this article:

Ibrahima Mall, Mahamadane Diène, Moctar Diaw, Papa Malick Ngom, Serigne Faye. Combination of Structural Data and GIS Tools in the Delineation of Groundwater Potential Zone in Crystalline Terrain: The Case of Southeastern Senegal. Journal of Water Resources and Ocean Science. Vol. 8, No. 6, 2019, pp. 94-107. doi: 10.11648/j.wros.20190806.12

Received: October 2, 2019; Accepted: October 30, 2019; Published: November 9, 2019

\begin{abstract}
In some West African regions, the craton is made by birimian formations that constitute the basement in these areas. In Senegal, the Kédougou Kéniéba inlier is characterized by the presence of fractured aquifers, thus constituting a problem of availability and mobilization of groundwater resources in this zone. Evaluation of groundwater potentiality zone is studied by using Remote Sensing and GIS technics integrating eight thematic parameters (Rainfall, geology, lineaments, regolith thickness, and weathered thickness proximity of rivers). The weighted overlay technic is used and appropriate weight were evaluated by statistical approach with a linear regression model in order to determine and built influence percentage of groundwater storage related to each parameter. Results showed a map of five groundwater potential classes ranging from very good to very low potentiality. High groundwater potential areas are located in the southern part of the Sabodala mining area and contrast with the northern part where groundwater potential is low due to lower rainfall and rock types dominated by granite formations in most parts of the area. Very good potentials occupy about $5 \%$ of this study area. These areas are mainly located in the southern part of the Gambia River watershed between the isohyets 1250 to $1150 \mathrm{~mm}$ and on the MTZ. Areas with good potential are mainly found on volcano-sedimentary formations, but they are more concentrated on the southern part of the Gambia watershed where interesting flows can be observed $\left(8\right.$ to $\left.20 \mathrm{~m}^{3} / \mathrm{H}\right)$. This result is in compliance with the flow rate data observed in this southern part. On the other hand, the moderate potentialities constitute the class which is found on all lithology types and represent $35.1 \%$ of the total surface of the study area $\left(1280.6 \mathrm{Km}^{2}\right)$. However, the very low potentialities are only found in the northern part and occupy an area of 873.10 square kilometers corresponding to $10.5 \%$ of the total area of the area. These results confirm that in the northern part and the granitic terrains have weak potentialities and the risks to get a negative boreholes remain high at these zones. Results show that there is a good correlation between the good potential areas identified by the GIS and the areas with appreciable borehole yields and the tectonic basins.
\end{abstract}

Keywords: Kédougou Kéniéba Inlier, Crystalline Terrain, Groundwater Potential Delineation, Geographic Information Systems, Remote Sensing

\section{Introduction}

In the sub-Saharan regions, problems of water availability and mobilization are increasingly felt particularly in crystalline basement regions where aquifers remain very unproductive.

Today, the natural region of eastern Senegal, which is relatively steep compared to the rest of the Senegal Republic is very attractive because of its numerous mineral resources, exploration, and exploitation of its gold mines. The gold rush has now favoured the development of villages such as Sabodala, Tinkoto, Bantako, Diabougou, and Sambarabougou, to name but a few, which host a massive influx of people from neighbouring countries and the sub- 
region of West African region. This situation makes the demand for community drinking water supply (DWS) more than a priority and remains a challenge for the state of Senegal and its development partners to achieve the Millennium Development Goals (MDGs) transformed into Sustainable Development Goals (SDGs) after 2015. In this region characterized by the absence of generalized groundwater resources and relatively high failure rates boreholes drilling, the main groundwater resources are localised in weathered, and fractured aquifers and, the shallow alluvial aquifers along major rivers. These very unproductive and difficult to locate aquifers are subject to a great pressure linked to gold washing activity which is now widespread throughout the region and consume a great amount of water. This activity has direct impact on the quality and quantity of groundwater resources in eastern Senegal, whose reserves are poorly known. This is not without consequences on the water resources in the region. The hydrogeology of this region of eastern Senegal has only been the subject of some pioneering work [1-8]. The methodological approach consisted in exploring the advantages of GIS tools combined with remote sensing for the delineation of favourable areas to boreholes implantation in this basement aquifer context. These concerns can lead to complex "scientific" issues, so it is important to note that the communities that rely on these groundwater resources live in poverty and isolation and access to groundwater resources remains very limited in some areas. The Kédougou Kéniéba Inlier, like many parts of the crystalline basement regions, belongs to the Birimian rock domain characterized by the presence of discontinuous aquifers. The hydrogeological system consists of fractured and altered aquifers, whose implementation is a function of the tectonic evolution and the climatic effects on these crystalline formations (alteration). Today several authors have shown the relevance of optical satellite imagery $[9,10]$ or radar $[11,12]$ or their combination [13] as a mapping tool in earth sciences (geology, mining, geomorphology, hydrogeology, civil engineering, geography, etc.) to identify favourable areas for borehole implantation. The systematic integration of these data, followed by hydrogeological investigations, provides an effective, rapid and economical delimitation of potential aquifer zones. Despite extensive research and technological advances, the study of groundwater has remained more than random, as there is no direct method that facilitates the direct observation of groundwater. Its presence or absence can only be asserted by indirect deduction based on the study of geological parameters and surface conditions. However the study of the structural evolution of these terrains, could be of a great contribution for facilitating the understanding and groundwater dynamic evolution on crystalline basement rocks [14]. The purpose of this paper is to combine geological and structural data and GIS and Remote Sensing tools for a better understanding and characterization of the aquifer potential in basement areas. These data could better explain the correlation between large tectonic structures and potential aquifer zones.

\section{Methodology}

The Landsat $\mathrm{ETM}^{+}$images (April 2010) and ASTER images were respectively processed using Erdas Imagine 9.2 and Arc Map 10.5. Landsat images were filtered to highlight the lineaments first by the low pass band filters $(3 \times 3$ filter) then directional filtering (Sobel $7 \times 7$ filter) are applied to the images. The ASTER image processing was carried out on Arc Map 10.5 with "Spatial Analyst tool" by the hydrology module which made it possible to generate the slopes. Thus, the lineament density is calculating by using the tool "line density" which calculates the density of linear elements in the vicinity of each output cell of the raster. The density is calculated in units of length per unit area $\left(\mathrm{Km} / \mathrm{Km}^{2}\right)$. The methodological approach adopted is based also on the description of the lithology of formations crossed by drillings from the stratigraphic logs of 66 boreholes. These show a great diversity of geological terrains in the Birimian of eastern Senegal. The stratigraphic analysis was carried out by the Rock Works software which allowed to model the extension and the variation of thickness of the different terrains crossed by the wells. The first step consisted in setting up the database that integrates the lithological and stratigraphic data of all the structures as well as their flow rates. The model first integrates the location data of the borehole (XY coordinate) and the $\mathrm{Z}$ (altitude of each of them) extracted from the SRTM images. On the basis of the stratigraphic information provided, the software makes it possible to correlate and restore a lithostratigraphical division. Thus, 4 stratigraphic units were identified: (1) the weathered unit, we define it here as the superficial formations that include soils, laterite, and clay minerals developing on weathered rock; (2) the Regolith unit, which represents altered rock in situ and which in turn rests on the fractured bedrock unit; (3) and the latter rests on the unfractured basement (4). However, the absence of one or more of these units may be noted in some areas. The characterization of the different aquifer reservoirs by a detailed study of logs of 66 boreholes was done with Rock Work in order to determine the different lithologies, weathered and fractured zone thicknesses and extensions. All input rasters were generated, reclassified, weighted, and overlaid using the "Weighted overlay" module. In order to determine importance and influence of each parameter in groundwater occurrence, a statistical analysis was performed. The data analysis was carried out by the $\mathrm{R}$ software which allowed us to make linear regression model which defines the flow rates as dependent variable and the other parameters as explanatory variables. This analysis takes into account parameters such as rainfall, borehole flow, lineaments, slope, proximity to major rivers, weathered thickness and fracturing thickness and determines the influence of each parameter (Figure 1). Table 1 summarizes the percentages of influence of the various parameters chosen in the model. 


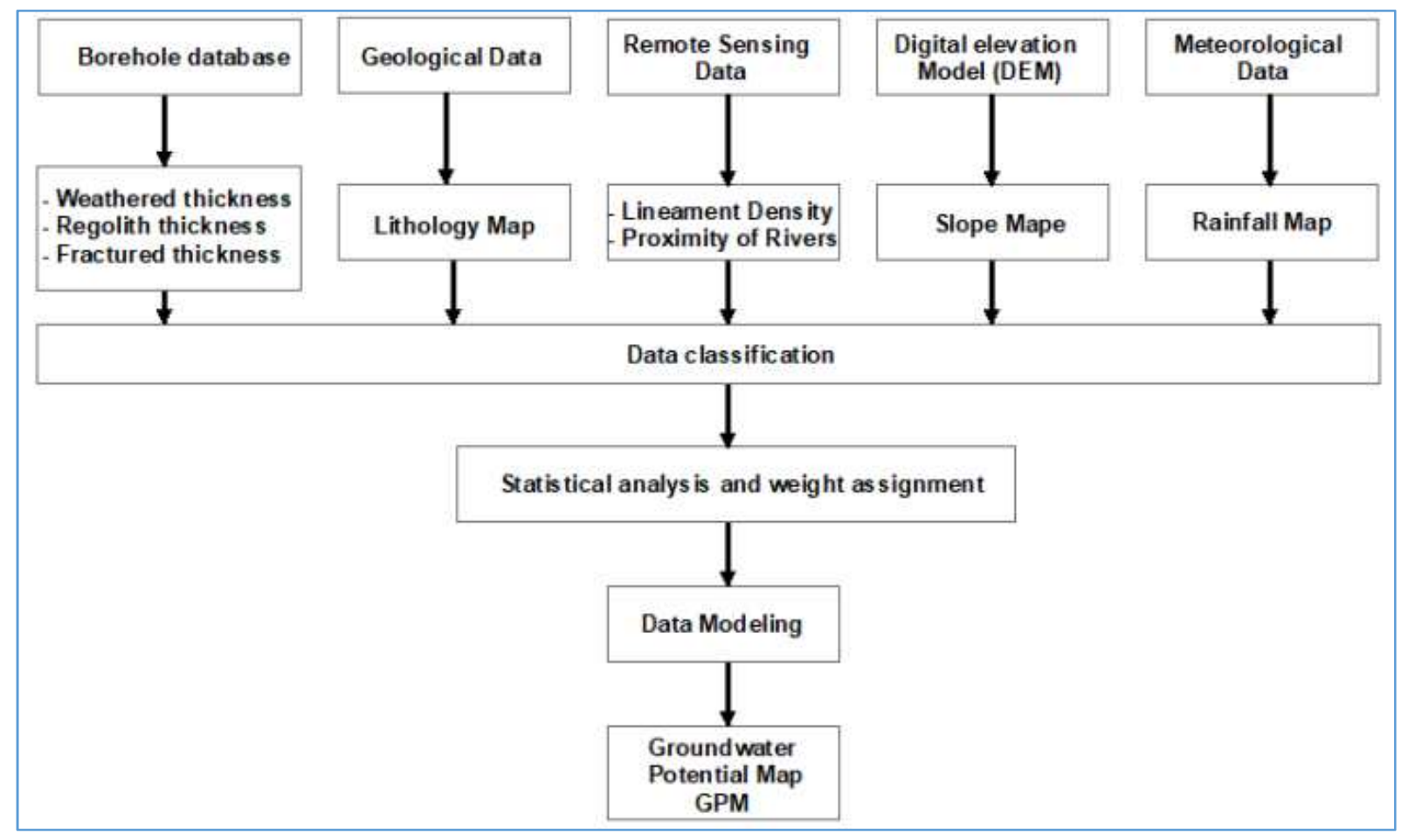

Figure 1. Methodology used in the study.

\subsection{Data and Tools}

Table 1. The classification and the weight of the influencing factors on the potentiality for groundwater storage.

\begin{tabular}{|c|c|c|c|c|c|}
\hline Classes & Very good & Good & Moderate & Low & Very low \\
\hline Weighted parameters & 9 & 7 & 5 & 3 & 1 \\
\hline \multirow{2}{*}{ Rainfal 25\% } & 2,25 & 1,75 & 1,25 & 0,75 & 0,25 \\
\hline & $1250-1150 \mathrm{~mm}$ & $1150-950 \mathrm{~mm}$ & $950-850 \mathrm{~mm}$ & $850-750 \mathrm{~mm}$ & $750-650 \mathrm{~mm}$ \\
\hline Geology $25 \%$ & VSS & RPB & RVB & GR & Dolérite \\
\hline Slope $15 \%$ & 1,35 & 1,05 & 0,75 & 0,45 & 0,15 \\
\hline$\%$ & $0-2 \%$ & $2-5 \%$ & $5-10 \%$ & $10-15 \%$ & $15-35 \%$ \\
\hline Proximity of major rivers $10 \%$ meter & $250 \mathrm{~m}$ & $500 \mathrm{~m}$ & $750 \mathrm{~m}$ & $1000 \mathrm{~m}$ & $>1500 \mathrm{~m}$ \\
\hline \multirow{2}{*}{ Thickness of regolith $10 \%$ meters } & 0,9 & 0,7 & 0,5 & 0,3 & 0,1 \\
\hline & $19-35$ & $12-19$ & $7,4-12$ & $3,7-7,4$ & $0-3,7$ \\
\hline \multirow{2}{*}{ Thickness of fractured unit (m) 5\% } & 0,45 & 0,35 & 0,25 & 0,15 & 0,05 \\
\hline & $29-47$ & $22,5-29$ & $16,8-22,5$ & $11,4-16,8$ & $0-11,4$ \\
\hline \multirow{2}{*}{ Weathered unit (m) 5\% } & 0,45 & 0,35 & 0,25 & 0,15 & 0,05 \\
\hline & $30-60$ & $22,4-30$ & $16,4-22,4$ & $10,7-16,4$ & $1,2-10,7$ \\
\hline Lineament density $5 \% \mathrm{Km} / \mathrm{Km}^{2}$ & 0,45 & 0,35 & 0,25 & 0,15 & 0,05 \\
\hline
\end{tabular}

\subsubsection{Rainfall}

Rainfall constitutes the most important parameter in groundwater recharge. Rainfall in the region is mainly concentrated during the wintering period, which begins at the end of April and continues until late October/early November in the southern part of the study area. In contrast, in the northern part, rains start later in late June and usually stop in early October. The highest precipitation is recorded in August in the two climatic provinces. The sector is characterized by a north-south rainfall gradient [5]. This is illustrated by a spatial distribution of isohyets showing a gradient that increases from north to south. The isohyet 1250 $\mathrm{mm}$ (Figure 2) is observed in the southern part of Kedougou and towards the northern part of the zone is the isohyet 650 $\mathrm{mm}$. This contrast between the climatic provinces also reflects a difference in the structure of plant communities. The southern part of the forest area is characterized by a high density of vegetation sometimes associated with gallery forests that follow the meanders of the thalwegs. Thus, going up to the northern part of the study area, the forest gives way to the savannah dominated by thorny vegetation, well adapted to drought conditions. 


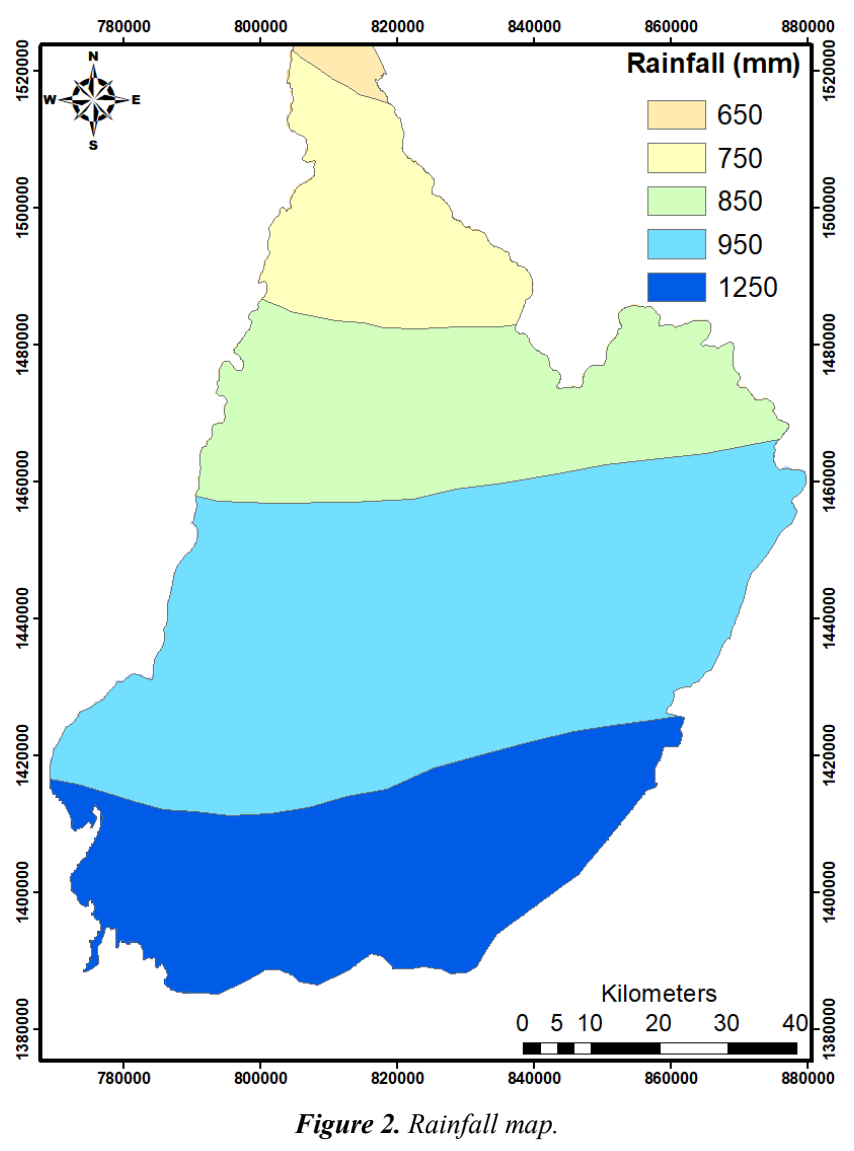

\subsubsection{Lineaments}

Usually, a lineament is defined as any observable geomorphic linear feature that can be attributed to geological structures, notably fractures or lithological contacts [15]. The analysis of lithological discontinuities (contact between different formations) or structural discontinuities (faults, fractures, Joints) [16] shows that some large families of lineation orientation are noted in the region. Lineament density of a region in an indirectly way uncovers the groundwater capability of that territory since the nearness of lineaments, as a rule, signifies a pervious zone. Regions with higher LD are useful for groundwater conservation [17]. The NE-SW directions (Figures 5-6) remain the most representative with more than $20 \%$ of the length of the total lineaments, followed by the NNW-SSE at NS and finally the EW direction which represents about $8 \%$ of the total length of lineaments. The preponderance of NE-SW is mainly due to major NE-SW faults [18] among which we have the regional tectonic accident called MTZ (main transcurrent zone). Fractures increase permeability and secondary porosity, thus, enhance vertical flow of water contributing to groundwater recharge. For this reason, fractures in rocks were considered to be a major factor and then included in identifying potential areas for groundwater storage [19].
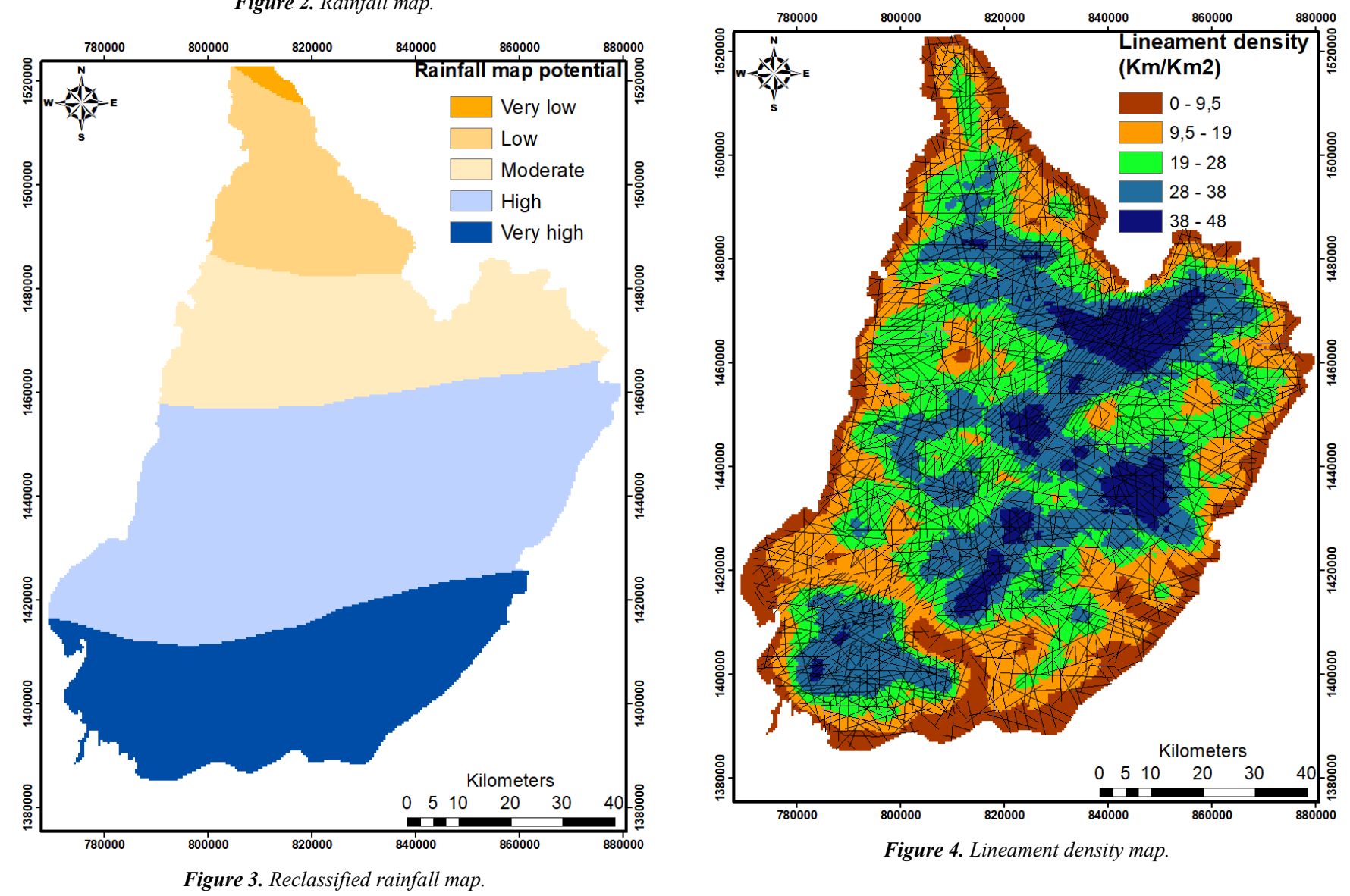


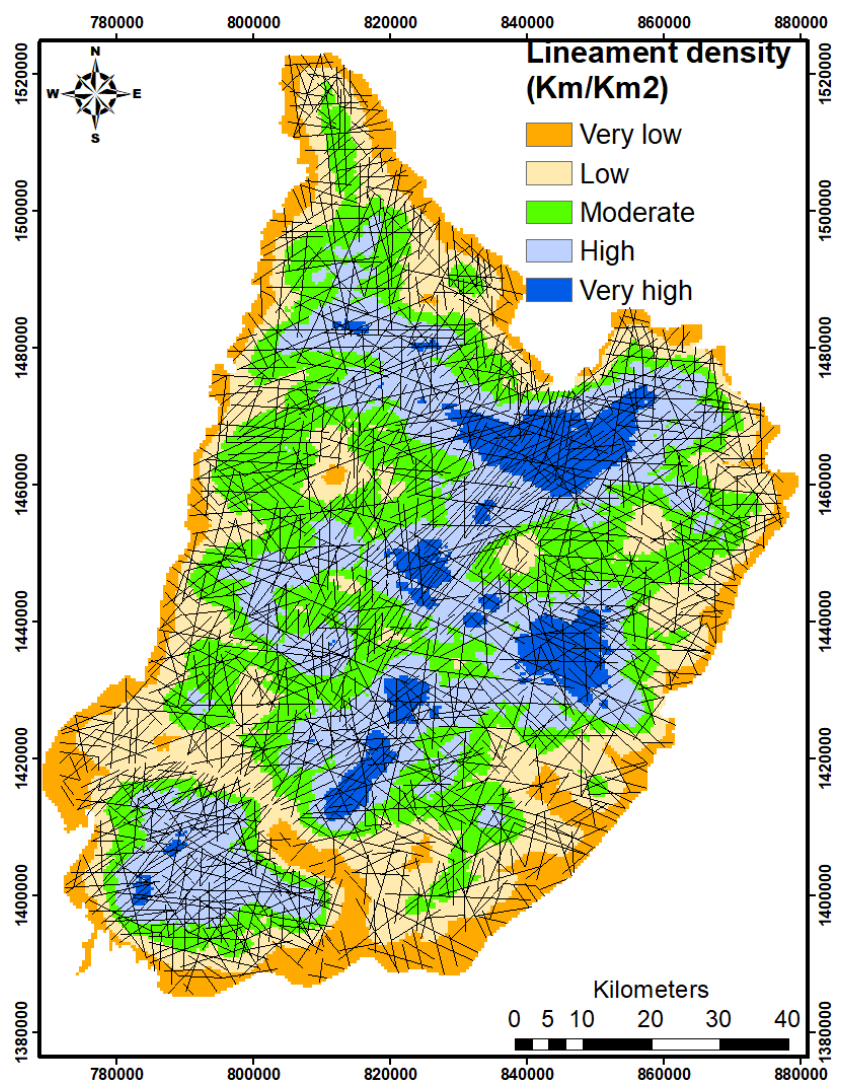

Figure 5. Reclassified lineament density map.

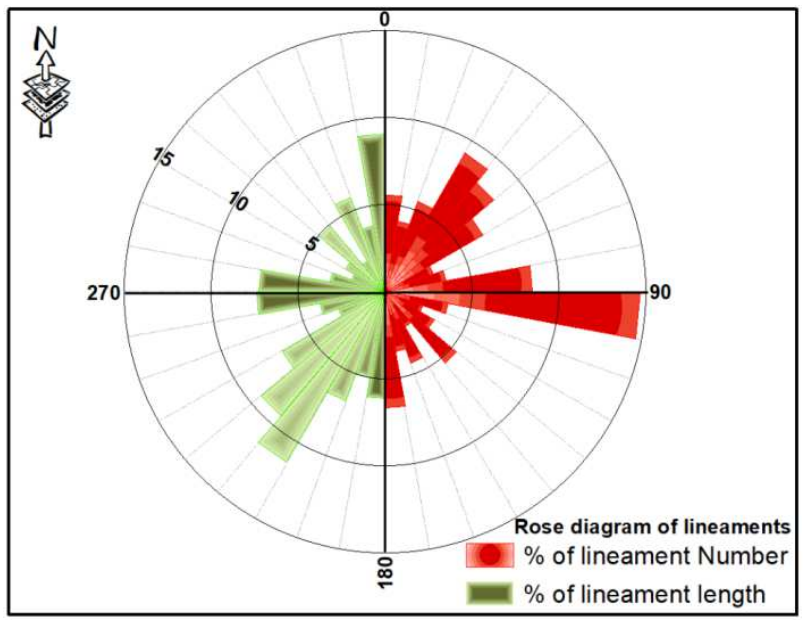

Figure 6. Rose diagram of lineamen direction and number.

\subsubsection{Geology}

Geological formations are an important factor in the development of groundwater storage in crystalline basement aquifers (Figure 7). Their petrography determines the type and profile of weathered that develops there. Thus, the thickness of the weathered units is much greater on the mafic rocks and schist than on granites [7]. However, more clay is developed on the basics rocks than on the granites where the weathered units are rather sandy. Due to their high Quartz content, granites are much more resistant to mechanical disintegration and weathering than other rock types. So granites could become good aquifers if they are well affected by faults. On the other hand, they become less so if they are not very structured because of the high resistivity of the granites to the alteration due to their high quartz content. Mafic rocks and schist may have good aquifer potential due to the fact that their weathering upper part is often well developed. This weathered layer constitutes the aquifer roof and develop a capacitive function and plays an important role in the delayed recharge of groundwaters in many cases. These laters being able to be useful and often exploited by the traditional wells villagers. Thus, the most interesting potentials are recorded at the level of mafic ultramafic formations and carbonate formations. Volcano-sediments can be good aquifers with good potential in groundwater storage. However, schist have moderate potential, so low potentials are observed on granites and acidic volcanic rocks.

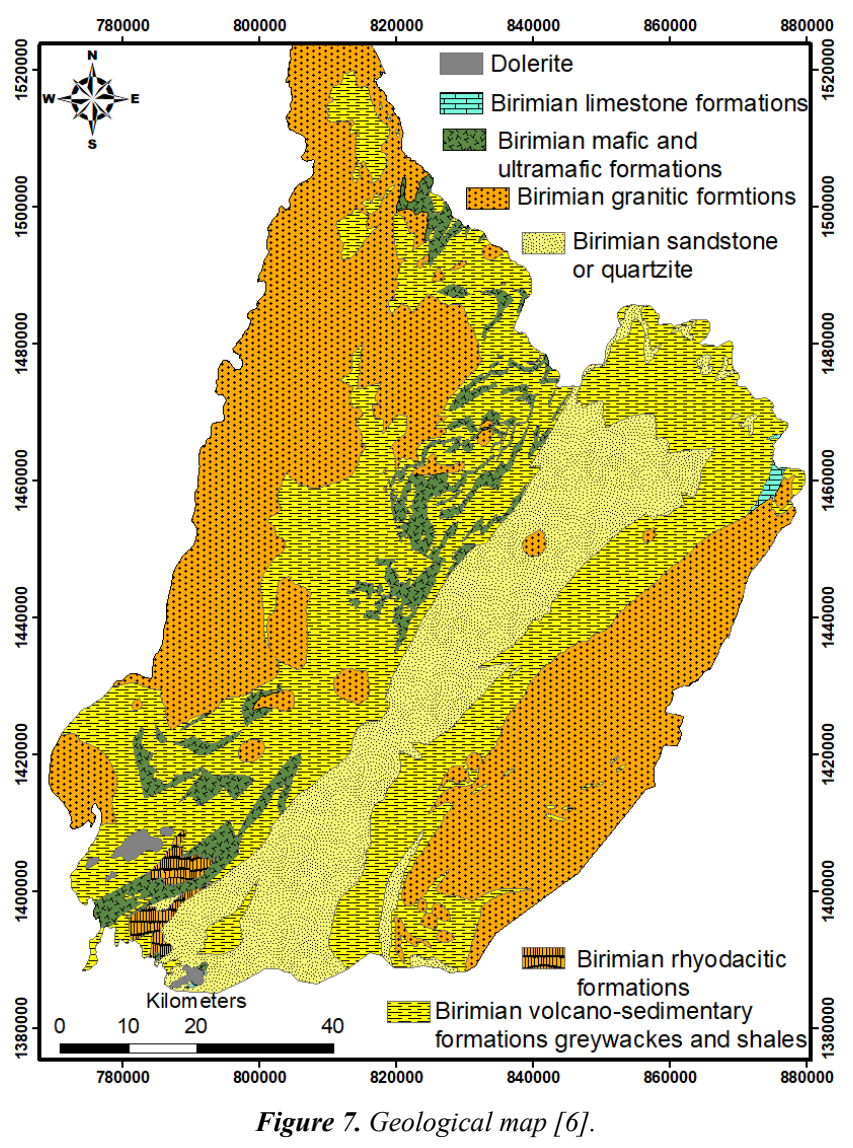

Slope of an area plays a very important role while evaluating its potential for groundwater occurrence. High slope areas produce more surface runoff and rainwater gets less time infiltrate [20].

The plain occupies most part of the area and the terrain is often marked by plateaus covered by a thick lateritic mantle. Slopes are higher especially in the southern west part of Kédougou in vicinity of Mako and in the center of the study area where they can reach $32 \%$ (Figure 9). The north side of the study area terrains become relatively flat with few elevations and gentle slope near the Falémé River. The elevations are more important in the south of the study area. This configuration of the geomorphology makes the terrains 
in the southern part, more conducive to runoff than infiltration, therefore less favorable to groundwater storage.
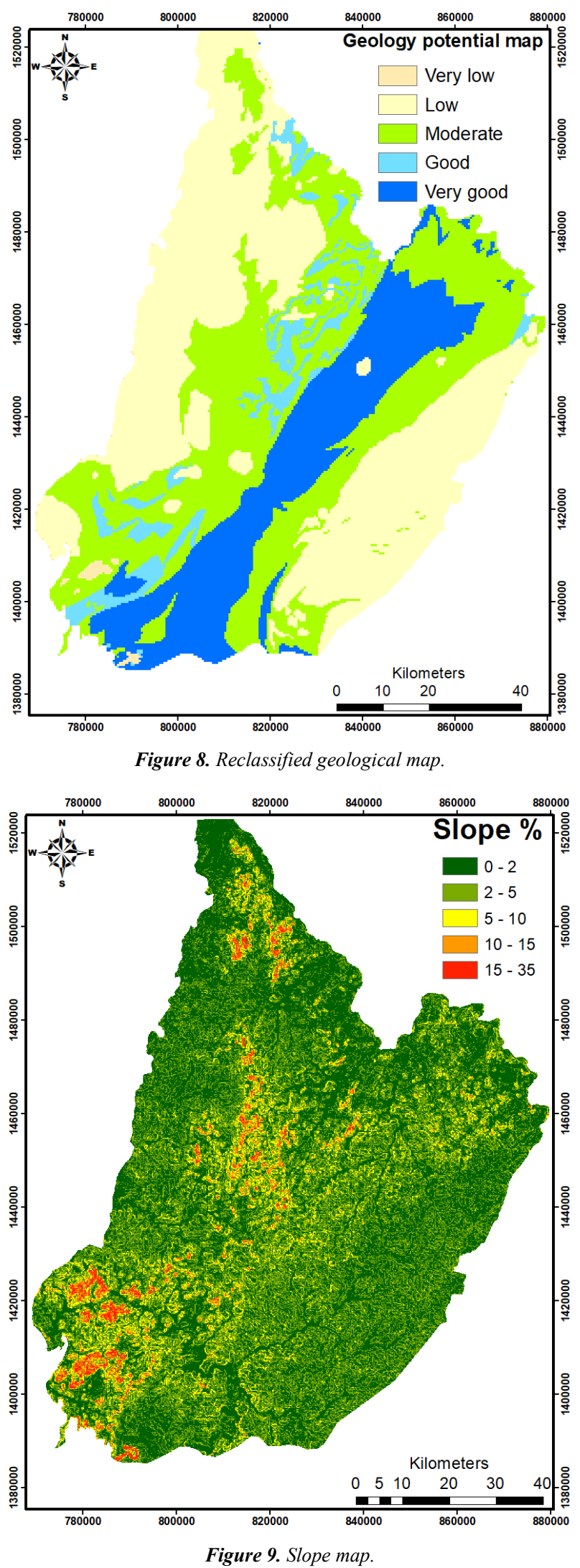

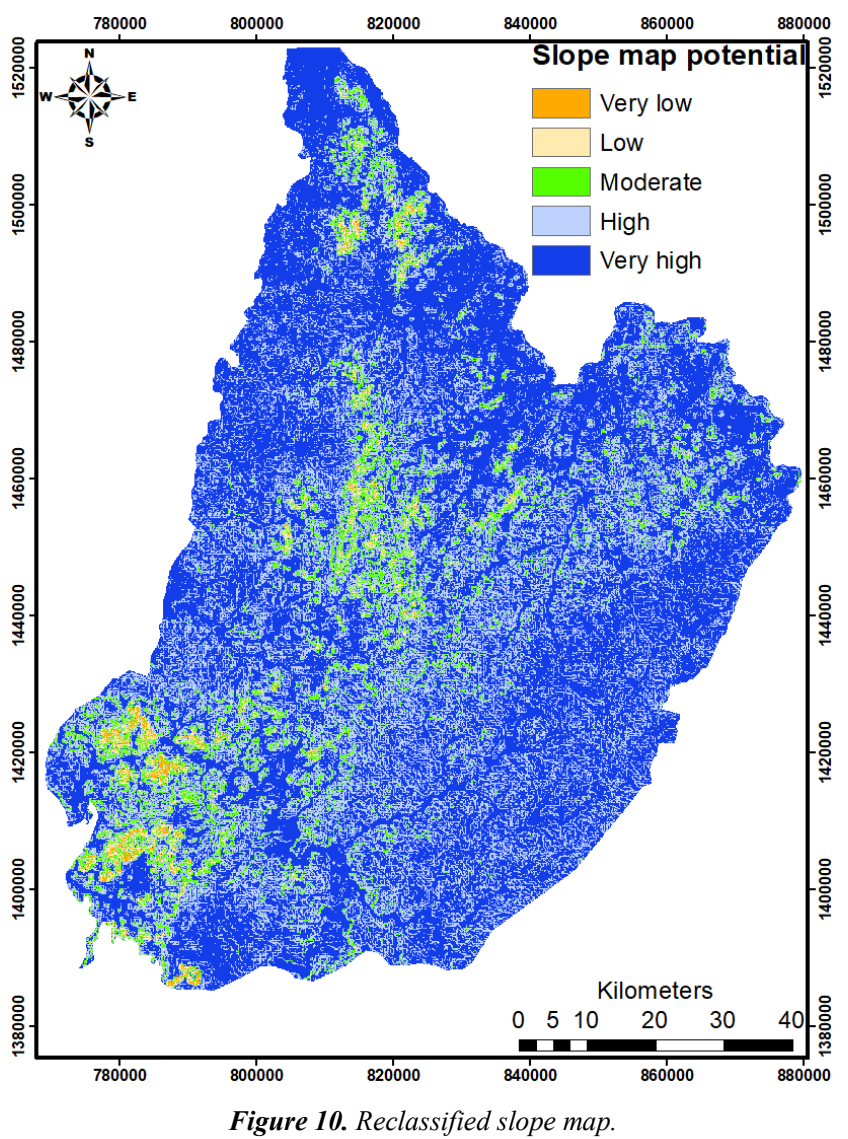

\subsubsection{Proximity of Major Rivers}

In the Eastern Senegal the Senegal, and Gambia River basins drain more than $79 \%$ of the total area of the region. These two major rivers are separated by a ridge that extends, in a direction NNW-SSE, from the Guinean border and the city of Toubacouta, through Saraya, Sabodala then to Koussane to the north. The Gambia River makes a big loop inside the region (Figure 12). Its major tributaries are the Koulountou, Niokolo-Koba, Sandougou, Thiankoye and Niériko Rivers, all of which have intermittent flows [21]. The Gambia is the only perennial river and crosses the entire basement region from east to west. On the other hand, the Falémé dries up in places during the advanced dry season. The flow of the Falémé River was observed for 60 years (1930-1989) at Kidira, a locality located more or less 35 kilometers upstream of its confluence with the Senegal River. In Kidira, the average annual flow or modulus observed over this period was $170 \mathrm{~m}^{3} / \mathrm{s}$ for an area taken into account of approximately $28900 \mathrm{~km}^{2}$, ie almost the entire river catchment area [22]. These two rivers can feed the alluvial aquifers with weak lateral extensions which can constitute good aquifers at villages scale. Thus, proximity of boreholes to these major rivers could be a success factor for drilling projects. 

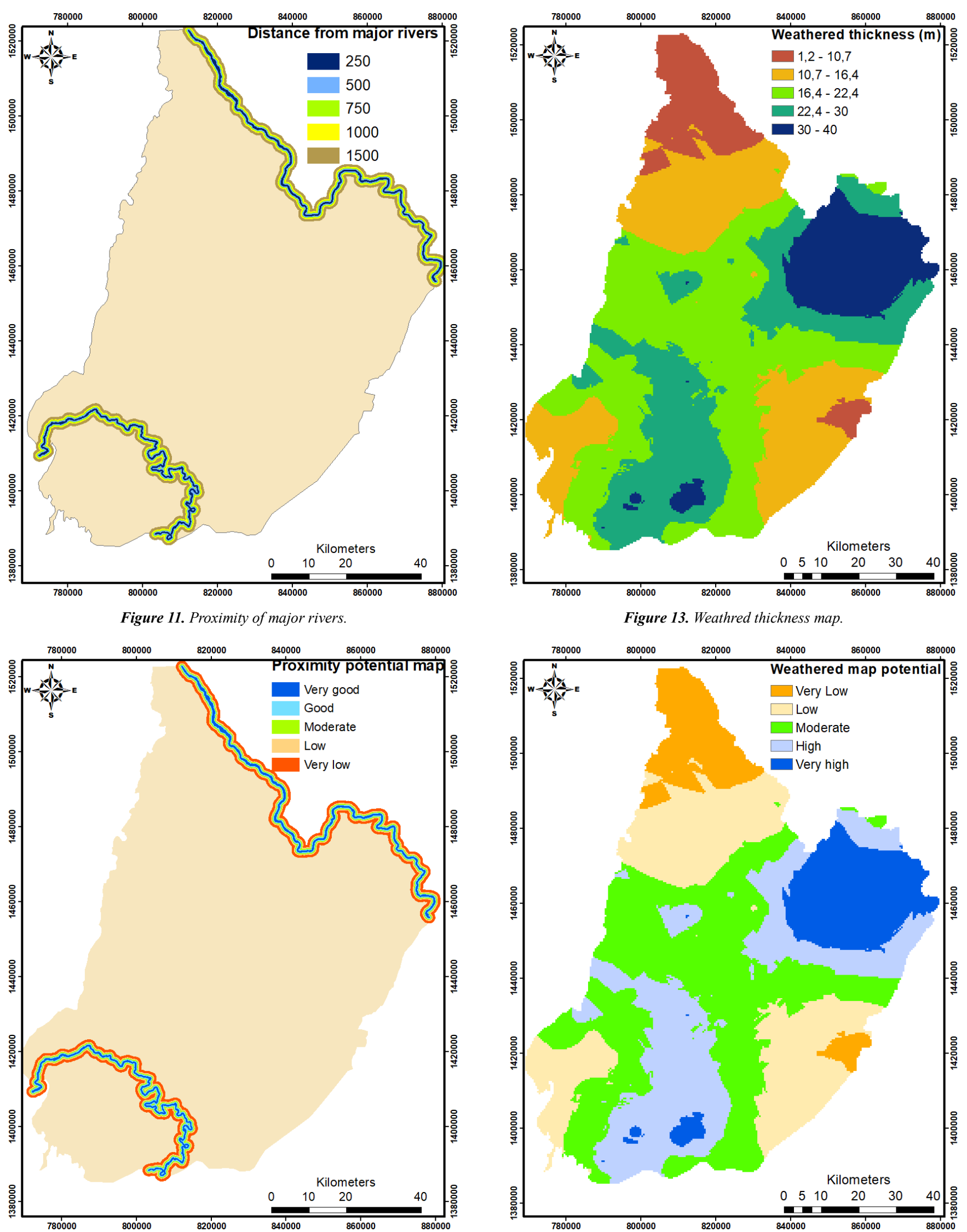

Figure 12. Reclassified proximity map.

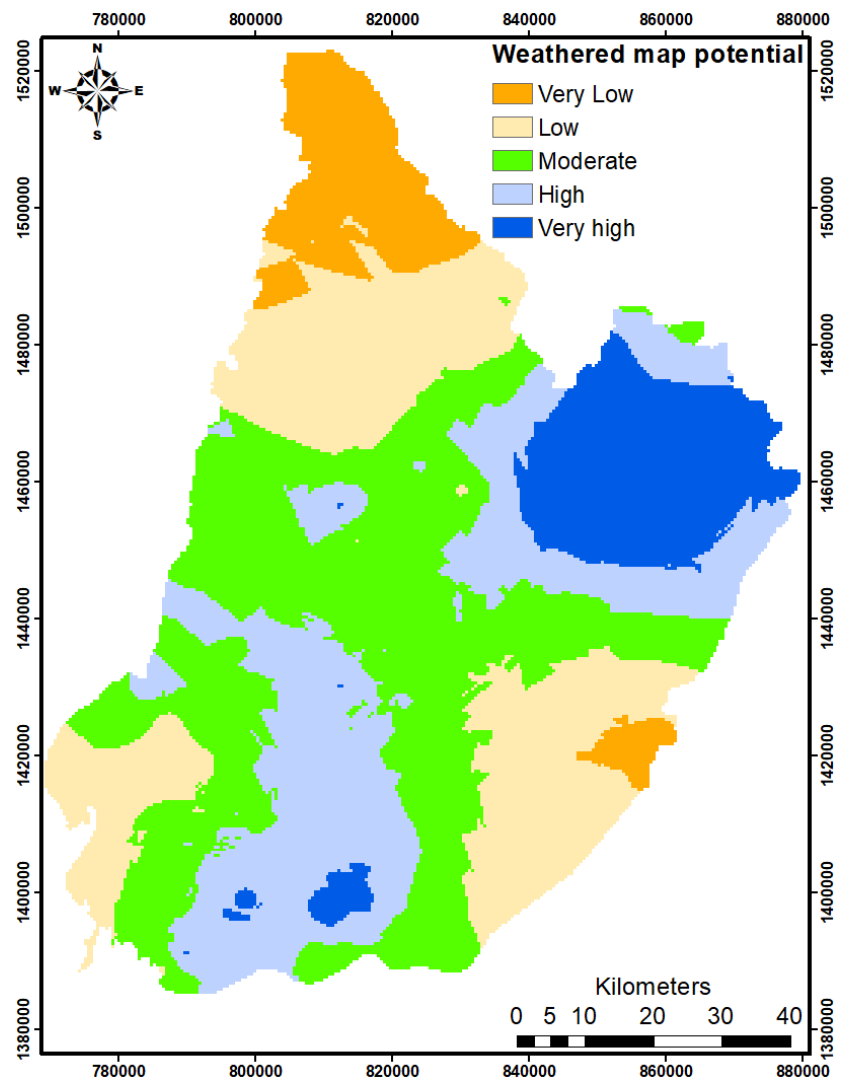

Figure 14. Reclassified map of weathered. 


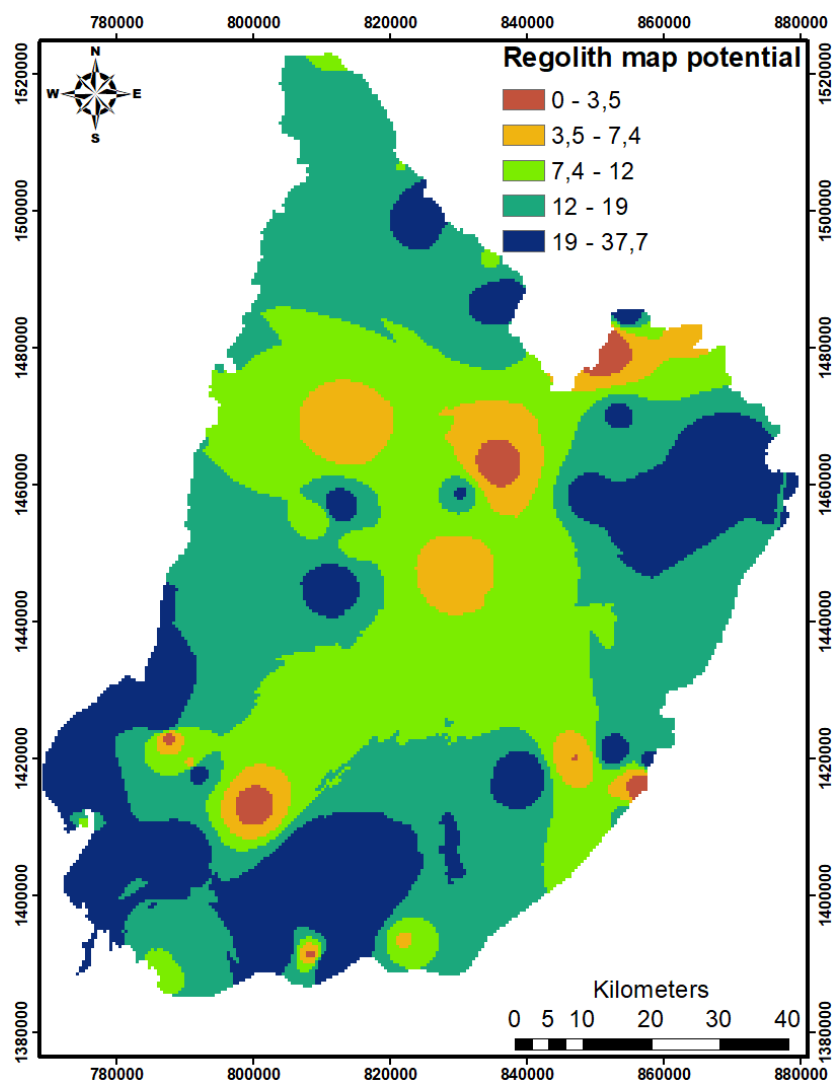

Figure 15. Fractured thickness map.

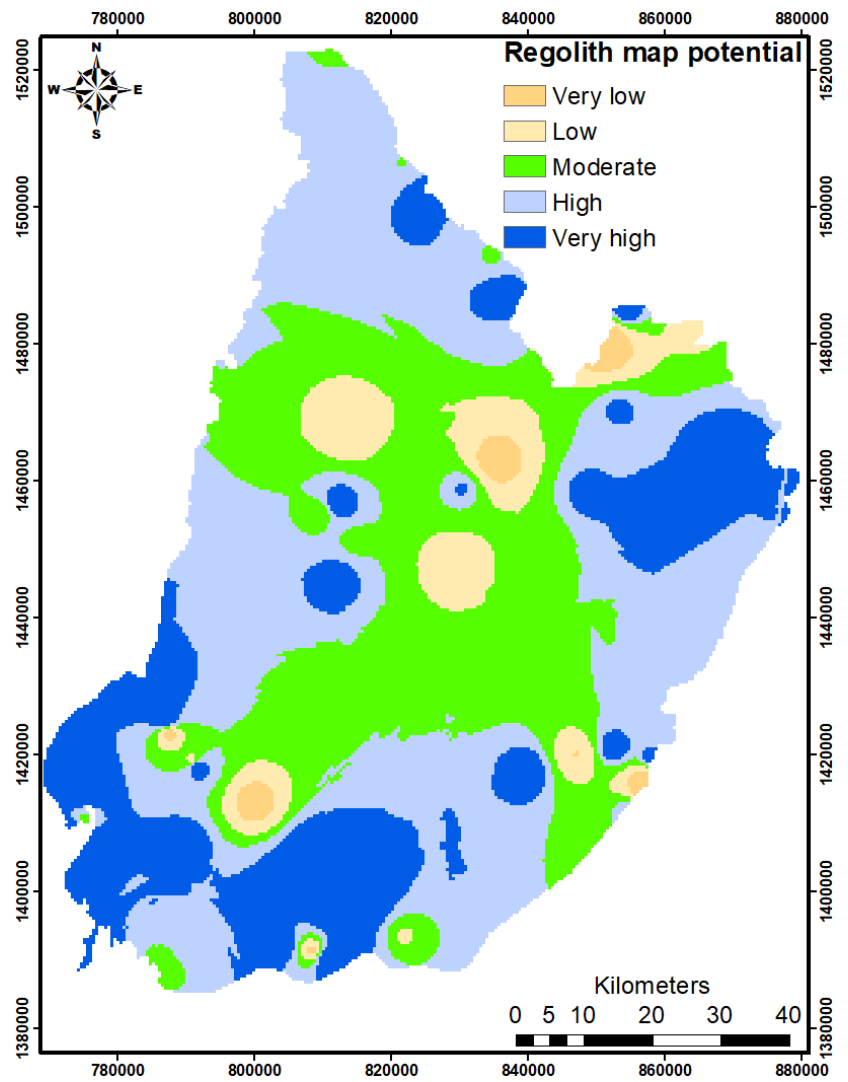

Figure 16. Reclassified fractured thicknes map.

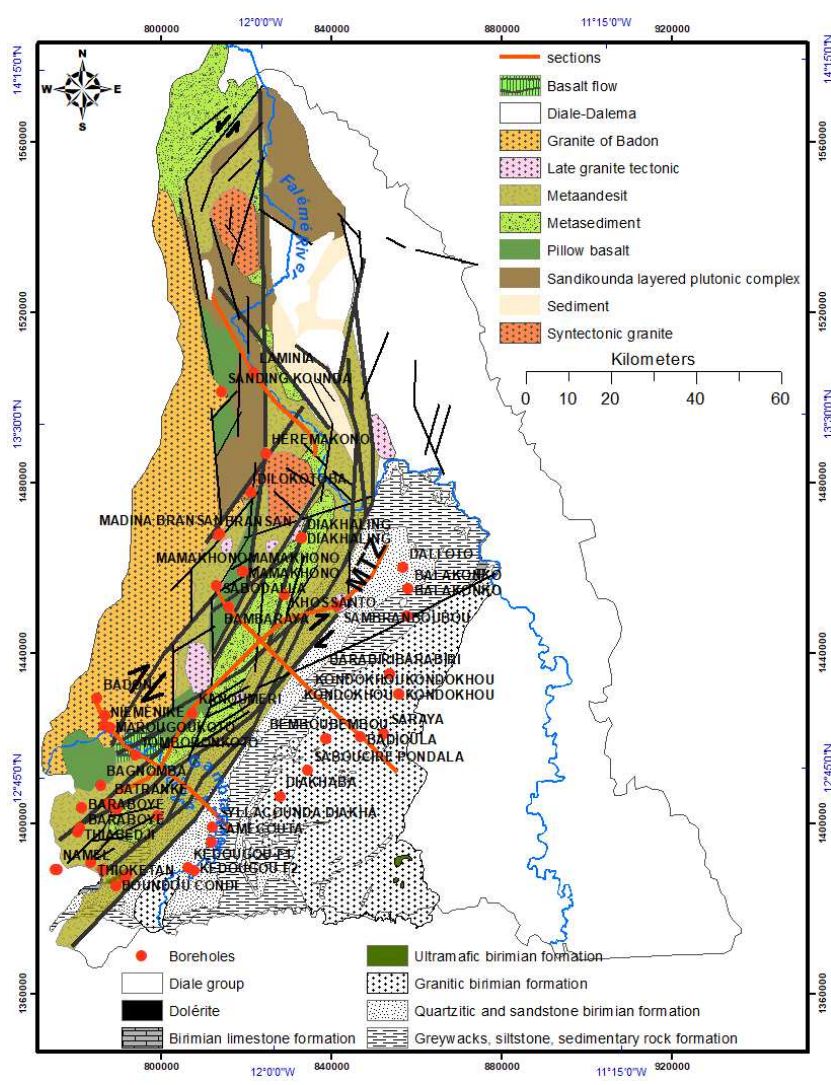

Figure 17. Lithostructural map and cross-section positions [21-23].

Drilling data show that the weathering profile is much more developed in the southern part of the region if we take into account the cross-section (A-A') (Figures 17-18), ranging from Sibikiling to Mako and along the Gambia River to Guingara with a relatively greater thickness of alteration (on average $25 \mathrm{~m}$ ) in this southern part of the region. On the other hand, to the north of the zone, the cross-section (B-B') (Figure 19) shows a profile that starts from Diabougou in the south to Dioumbalou in the north, there is a decrease of the thickness of the weathered profile from south to north with an average of 9 to $10 \mathrm{~m}$. This result is consistent with the hydroclimatic situation in the northern part of the zone, which remains with very sparse vegetation compared to the southern part. This section shows that the alteration is much less important in the northern part where the rains are less important and the evaporation more intense. The development of the fractured part is also weak and the unfractured basement is reached at relatively low depths exceeding rarely $50 \mathrm{~m}$. The predominance of granitic formations in the northern part is also an important factor in the development of weathered rocks at this level. The granites are less affected by alteration than other types of geological formations, which is not without consequence on the yield of the boreholes located in this northern part and more particularly on the granitic formations.

The cross-section (C-C') (Figure 20) is an SSW-NNE direction profile that starts from Folonkoto, crosses the MTZ and extends to Bokhody. It gives a clear overview on the evolution and the depth of the unfractured basement roof. 
The thickness of the weathered unit is very variable and the unfractured basement is also reached at very different depths. Fracturing remains highly developed in the Madankholy sector and this is a direct result of the Main transcurrent zone that affects the area. This intense alteration has a significant impact on the boreholes productivities localized on MTZ, the bulk of which has good flow rates. Concerning arenas, they develop mainly on dolerites (Kanouméring and Sambarabougou), on granit (Tinkoto), on sandstone (Madankhloy). The weathered rock unit often consists of granite arenas or balls of dolerite characteristics of the doleritic weathered which develops a presence of a clay layer on the roof of its arena.

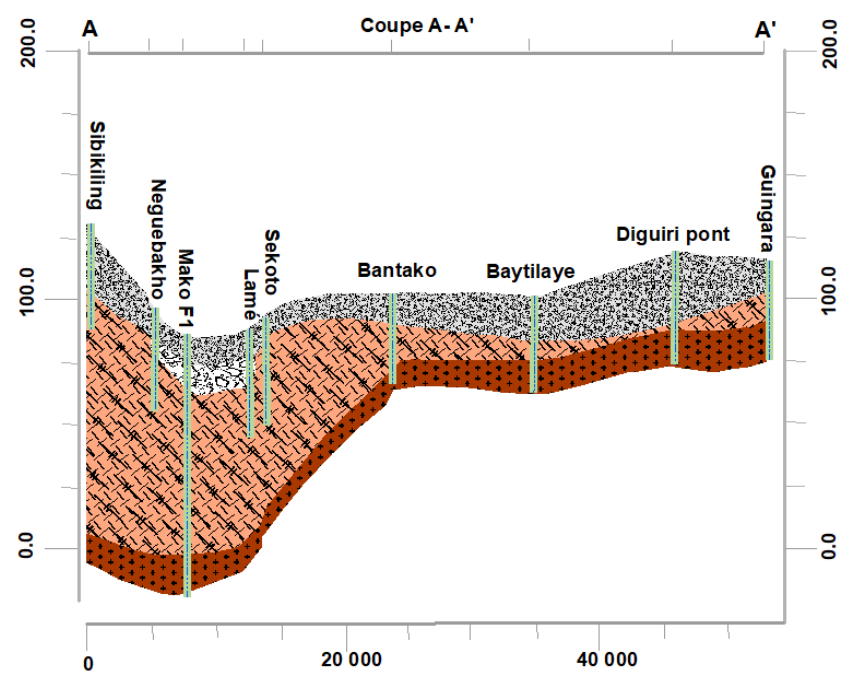

Figure 18. Cross-section (A-A').

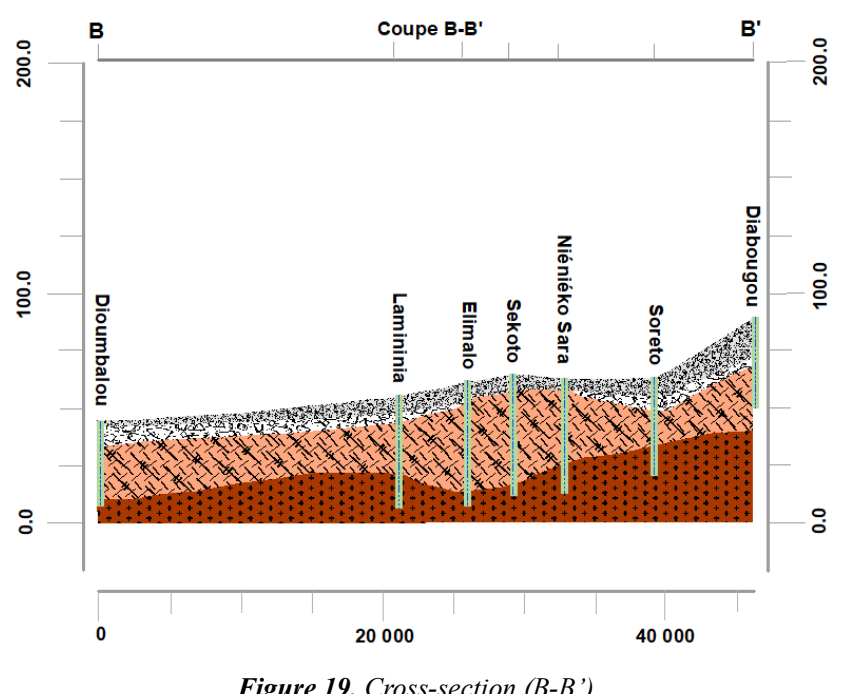

The section (D-D') (Figure 21) starts from the Sabodala zone situated in relatively high altitude and crosses the MTZ and a part of the Saraya granite to the village of Sanela. It shows an evolution of the thickness of the weathered unit much more developed on the mafic volcanic formations of the Mako group. This weathered unit decreases gradually from Massamassa towards the granite where the unfractured basement is reached at less than $50 \mathrm{~m}$ of depth. It should be noted also a more important development of arenas on the granites than on the other geological formations. This could be an important factor in the recharge of the underlying aquifers because of the high secondary porosity that can develop on these types of formation thus improving the performance of boreholes in these areas with high transmissivity.

As for the fractured units, they show a much greater evolution of fracturing on the MTZ (C-C') at Madankholy and at Mako (A-A' section) probably related to the Mako shear zone with respective average thicknesses around 50 to $75 \mathrm{~m}$. On granitic formations, this unit is less developed (sections B-B 'and D-D') with average thickness exceeding rarely $20 \mathrm{~m}$. This fracturing is a function of the rock decompression limit which often does not exceed $60 \mathrm{~m}$.
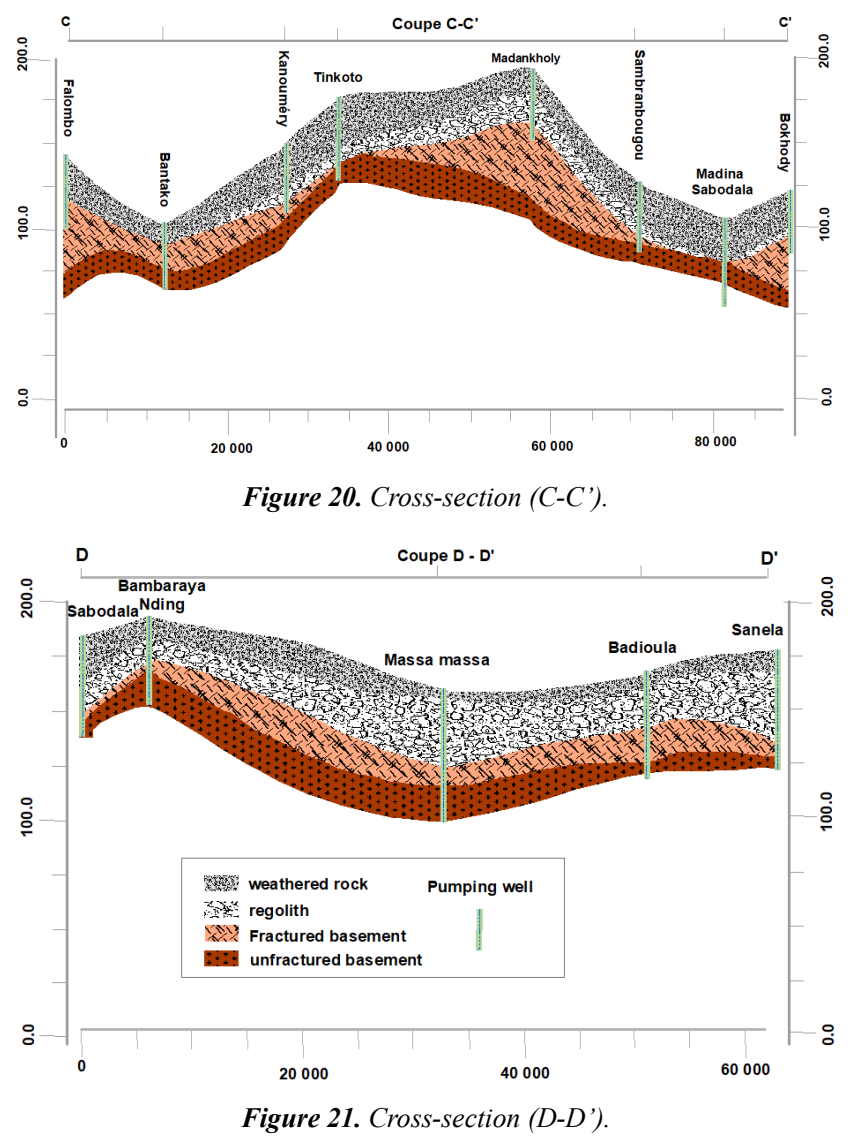

\subsection{Structural Data}

The structural evolution of the sector of Mako, has led to the development of large structures whose implementation and its development was made during the entire Eburnean orogeny and which are at the origin of its current structure. The Mako volcanic belt, show a structural evolution characterized by a well-defined context marked by transpressive tectonics with two deformation styles constituting a continuum. This transpressional tectonic deformation is at the origin of the establishment of accidents of directions NE-SW, N-S, E-W and NW-SE affecting the volcanic belt. These structures have a certain relation with an 
evolution starting from the segmentation of the belt while passing by the formation of the intrabrands and marginal basins, the pull apart [18-23].

The analysis of the lithostructural map (Figure 17) highlights two types of basins: the edge basins of green rock panels and basins located inside the first. These will be called type II basins. All these basins are delimited by NE-SW to N$\mathrm{S}$ tectonic structures, which can constitute facies boundaries.

They are located at the edges of the green rock belt (Figure 17). These basins surround the green rocks and are bounded by NE-SW to N-S faults such as the MTZ and the BadonNiéniéko shear zone system, the LMZ.

These types of basins are common in strike-slip corridors and are true isoclinal folds that are filled by sedimentation and troughs effect, with detrital filling and raised erosion margins that are often eroded, often more or less overlapping, and accompanied by significant volcanism. This folding associated with the uplift of the lithological pile, will lead to the creation of marginal basins whose filling will be byproducts of dismantling rocks constituting its elevated margin, but also by a mafic and calco-alkaline volcanism. The lithology in the Mako Supergroup's marginal basins consists of andesitic conglomerates that laterally cross the andesites (massive lava) in the east part. However, in the central parts, this evolution is interrupted by detrital metasediments that appear in the middle of the andesitic complex, with a posterior placement and a different control.

The setting up of these basins would be due to the activity of the N-S faults framed by major faults NE-SW. These N-S faults would constitute transforming faults that would have relayed the senestrial motion of NE-SW accidents, thus creating the formation of openings or basins inside the edge basins.

The observation of the geological map of the study area shows us the existence of such basins having evolved in pullapart including the Tinkoto basin (Figure 17), and the molasse basin of the north of Tourékhoto. All these two basins formed along the MTZ to the south and north respectively.

The creation and evolution of these basins were made under tectonic control. Rotation of the shortening constraint of NNW-SSE; NW-SE at WNW-ESE, transitions from an NS transpressional regime to a transpressive NE-SW dextral regime flanked by major NE-SW faults whose effects will lead to the creation of pull-apart basins including that of Tinkoto. The combination of the dextral strike of these faults will favour the birth of a zone in extension whose evolution will contribute to the opening and the formation of this basin. Its filling will be under tectonic control with coarse detrital inputs accompanied by a synsedimentary calc-alkaline volcanism but also by volcanodetritic products. These detrital inputs consist mainly of conglomeratic, grauwackous and gréso-pelitic levels.

Transpressive evolution would be synchronous with basic to intermediate volcanic activity represented by massive basalts and the andesitic complex and formation of basins. The filling of these, will be done gradually and synchronously to the deformation, by volcanic and volcanodetritic products of mostly andesitic nature, but also detrital.

\section{Results}

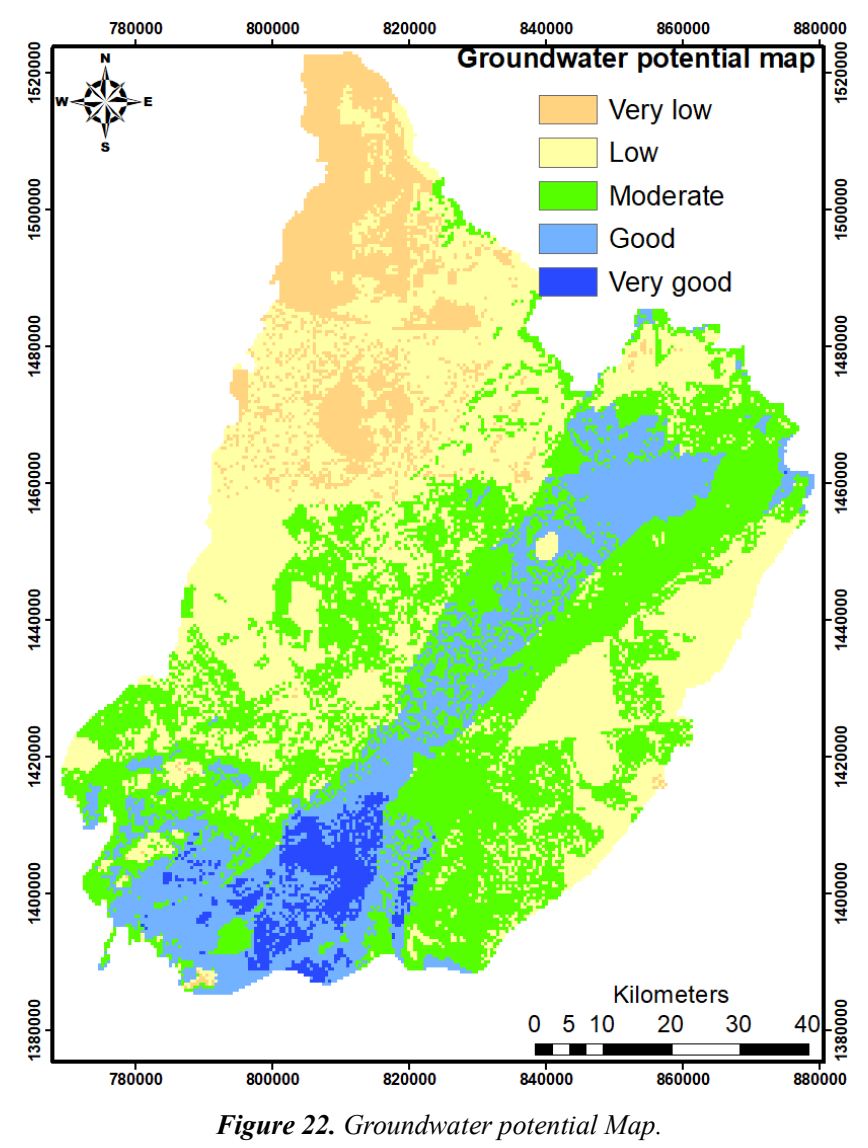

Areas of high aquifer potential are located along the Gambia River, south of the Gambia watershed and on the MTZ (Figure 22). These sectors are thus privileged areas for the search for zones favourable to the implantation of drilling mainly to obtain high flows. These zones represent $3.15 \%$ of the total zone area, ie $256.8 \mathrm{~km}^{2}$. Areas with good potential are mainly found on volcano-sedimentary formations, but they are more concentrated on the southern part of the Gambia watershed where interesting flows can be observed ( 8 to $20 \mathrm{~m}^{3} / \mathrm{H}$ ). This result is in compliance with the flow rate data observed in this southern part. They are also found on the MTZ at Madankholy, towards Kossanto. On the other hand, the moderate potentialities constitute the class that one finds on all the types of lithology and represent $35.1 \%$ of the total surface of the study area with an area of $1280.6 \mathrm{Km}^{2}$. This class is mostly found in granites and in the northeastern part. This fact can be related to two phenomena: either the drilling is implanted on a major tectonic accident or it is implanted near a hydraulic axis (tributary of watercourse) generally guided by the fracturing (case of the Diaguiri boreholes). The low potentials are mainly encountered in the northern part and more particularly on the granit of Sandikounda Soukouta. Results from GIS model show that volcano-sedimentary formations of the Birimian have the 
best aquifer potential. The very low potentialities are only found in the northern part and occupy an area of $873.10 \mathrm{Km}^{2}$ or $10.5 \%$ of the total surface of the area.

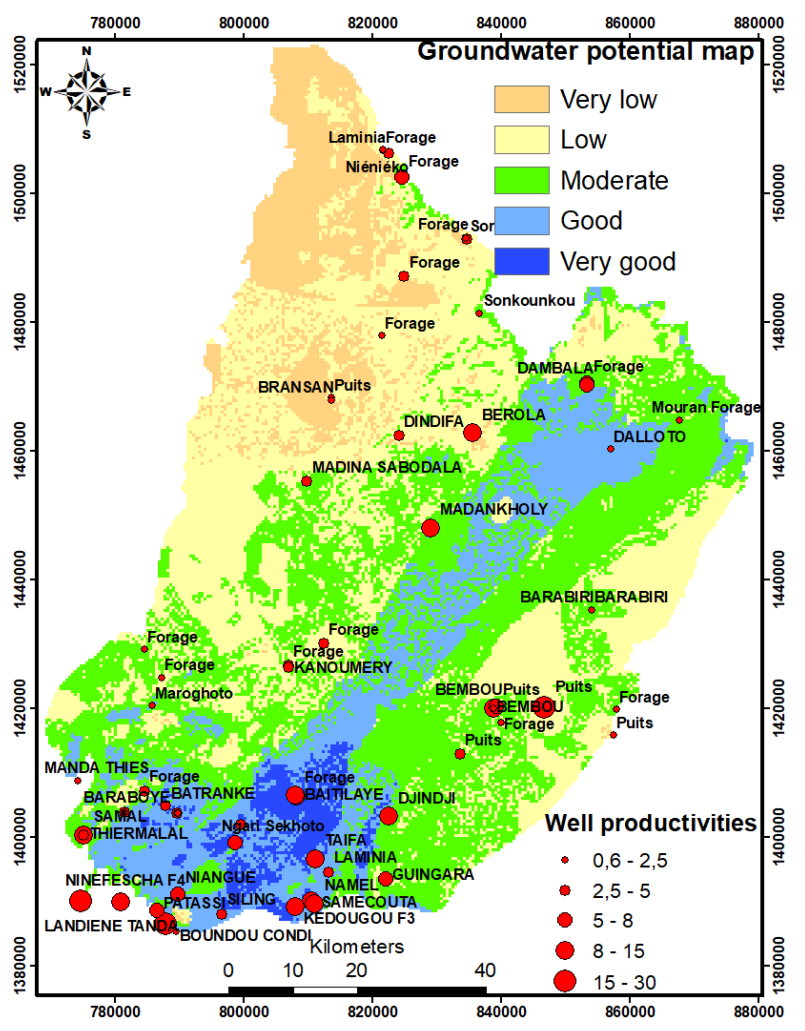

Figure 23. Groundwater potential and borehole yields.

\section{Discussion}

These results confirm that in the northern part and the granitic terrains have low groundwater potentialities and the risks of getting negative boreholes remain elevated at these levels. Unlike areas with low potential, areas with high potential remain the most interesting areas in South-eastern Senegal, because it is only in these areas that are observed borehole yields sometimes greater than $20 \mathrm{~m}^{3}$. A wary perception of the GWPZ map demonstrates that the arrangement of groundwater is more or less replications of the precipitation and geological formations beside slope [2426]. These areas, therefore, constitute preferred sites for drilling implantation for sufficient groundwater productivities. However, in some areas although the area having a good potential, low drilling rates have been noted: this is the case of the Mako sector located at high altitude. These low flows can be related to the quality of the boreholes' realization of or especially to a bad choice of their implantation sites. Accordingly, the groundwater potential zone map deciphered can be useful for hydrologists in detecting new zones of potential groundwater [27-28]. These results of the model could be refined if they are coupled with a complementary structural analysis that can give more precise indications on the real hydraulicity of the fractures and a good understanding of these basement environments in order to carry out a correct interpretation of results generated by the GIS.

\section{Method Validation}

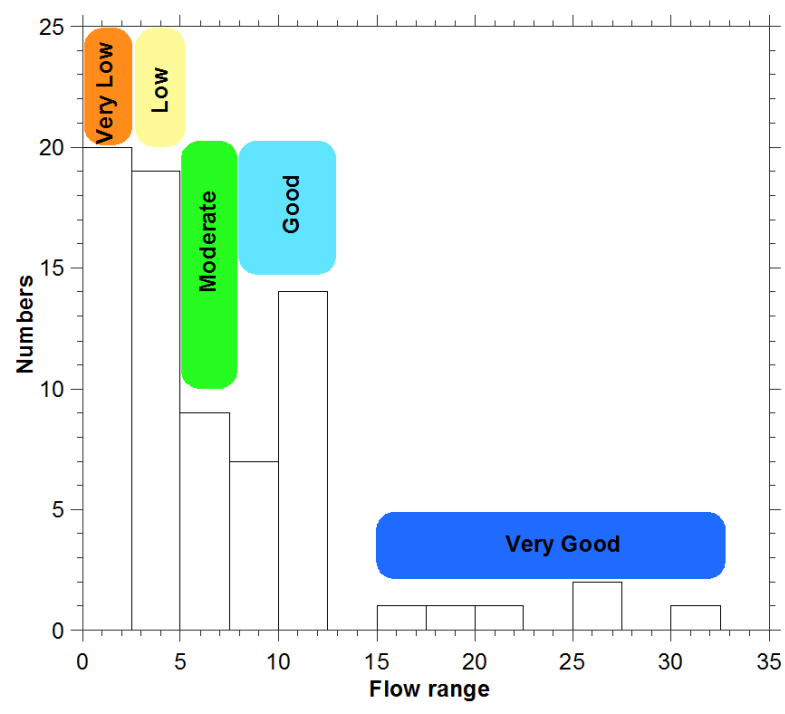

Figure 24. Frequency diagram showing well yield distribution.

Models will not have scientific significance without validation process [29]. To evaluate the accuracy of the model, we use the flows as validation data. In Table 2 the columns represent the flow rate classes and the rows represent the predictions in terms of potentiality. Thus, to test the accuracy of the model we studied the correspondence of the classes of flow rate compared to the classes of potentialities predicted in the different sectors. For this, we defined three flow rates classes: low (class 1), moderate (class 2) and high (class 3 ) flow rates (Figure 24). From these flow rates classes, we used the tool "extract value to point" in "spatial analyst tools" to have the correspondence of the flow classes to the results of predicted potentialities. The table gives all the values predicted by the model as well as their correspondence with the actual flow rate classes. This enabled to calculate the frequency of correspondence of each class with respect to the values of potentialities predicted from the "frequency" tool in Arctoolbox. The result is recorded in the frequency table (Table 2). The latter allowed us to determine the error matrix between the different classes by using the tool "pivot table" (pivot table) always in Arctoolbox (table 3).

Table 2. Frequency of correspondence of flow classes with the potential classes predicted by the model.

\begin{tabular}{lll}
\hline Classes & Prediction & Frequency \\
\hline 1 & 1 & 15 \\
1 & 2 & 12 \\
1 & 3 & 7 \\
2 & 1 & 1 \\
2 & 2 & 5 \\
2 & 3 & 2 \\
3 & 1 & 7 \\
3 & 2 & 6 \\
3 & 3 & 14 \\
\hline
\end{tabular}

$1=$ Low yield; Low potentiality; $2=$ Moderate yield, Moderate potentiality; $3=$ High yield, High potentiality. 
Table 3. Error matrix.

\begin{tabular}{|c|c|c|c|c|c|}
\hline Classes & Prediction & Low yield 0-5 $\mathrm{m}^{3} / \mathrm{H}$ & Moderate yield 5-8 $\mathrm{m}^{3} / \mathrm{H}$ & High yield $>8 \mathrm{~m}^{3} / \mathrm{H}$ & Percentage of accuracy \\
\hline Low Potentiality & 1 & 15 & 1 & 7 & $61,21 \%$ \\
\hline Moderate potentiality & 2 & 12 & 5 & 6 & $21,76 \%$ \\
\hline High potentiality & 3 & 7 & 2 & 14 & $60,86 \%$ \\
\hline
\end{tabular}

These results show that the low potential class has the best accuracy with 15 low flow rate values out of 23 (Table 3). This corresponds to a precision percentage of $61.21 \%$ in areas with low potential. On the other hand, the moderate potentiality class shows the lowest accuracy, on this category only 5 boreholes on 23 displaying moderate flows, ie $21.7 \%$ of the boreholes encountered in these moderate potential classes predicted by the model. However, for most of moderate potential zones low borehole flow rates are observed (12 out of 23 ), or $52 \%$ of the boreholes. These results show that in areas with moderate potential mainly located on granites, drilling success is random and requires precise studies in the selection of boreholes location, because in these areas with moderate potential, the probability get borehole with low flow rates remain very high $(52 \%)$ of the boreholes in these areas with moderate potential have low flows). However, in some sectors, even though the predicted potential is moderate, high flow rates have been noted: this is the case of the Badioula borehole, which although on the granite has a high flow rate $\left(19 \mathrm{~m}^{3 /} \mathrm{H}\right)$. These high flow values can be explained by the fact that the Badioula borehole is drilled on the sedimentary enclaves of the Saraya granite consisting of sandstone.

Regarding the good potential class, it shows good accuracy of the model with a precision of $60.86 \%$ or (14 of the 23 boreholes) that have good flow rates. However, in these areas with good potential, 7 boreholes have low productivities. This could be due to improper borehole positioning in relation to open conductive fractures which are hydraulically active, or a defective realisation of the borehole due to the drilling process.

Other lessons to be learned remain the fact that areas with low potential coincide well with areas with low flow boreholes, however, the only areas favourable to these levels are the areas near the major Rivers including Falémé and Gambia Rivers. However, it must be remembered that in these areas, the construction of boreholes with high flow rates remains to be excluded and an appropriate choice of drilling sites should be well done at this level to avoid unproductive boreholes.

However, it is necessary to quantify this uncertainty of the method. This makes it possible to better evaluate the value of the results which are presented because these results from modelling process can be altered by many elements that can affect the accuracy of the analysis. Some data analysis and the tools used are responsible for this potential loss of confidence in the results generated by the model. The mapping process is an example where uncertainties can be generated [22]. For example, slope values accuracy depends on the spatial resolution of image data used. Another example who can generate an error could come from the interpolation methods used, which predict results in areas without information. The accuracy of these predicted results will largely depend on the density of the measurement points in the area. Thus, the denser the observation points, the lower the error generated on the predicted value is. The discontinuous, and very heterogeneous nature of the basement terrain combined with fracturing and often an important thickness of weathered cover in these environments increase the risk of errors in this type of analysis.

\section{Conclusion}

The investigations for favourable zone drilling implantation in the crystalline basement areas constitutes a major challenge for the water supply in these disadvantaged zones presenting a low aquifer potential. The results showed that the very low potential represents $10.50 \%$ of the total area of the study area and corresponds to $873.10 \mathrm{~km}^{2}$ these areas are located mainly in the northern part of the SandikoundaSoukouta granite. On the other hand, the low potentialities are distributed on the majority of the granitic terrains (Saraya and Sandikounda-Soukouta) and occupy $35.9 \%$ of the total surface of the study is $2987.62 \mathrm{Km}^{2}$. Moderate potential occupies the same areas and is found in all terrain types mainly on granites, but also on volcano-sediments and mafic rocks. However, the good and very good potentialities are about $18 \%$ of the area of the study area and are mostly located in the volcano-sedimentary formations and in the southern part of the study area. Results show that there is a good correlation between the good potential areas identified by the GIS and the areas with appreciable borehole yields and the tectonic basins. The characterization of the different aquifer reservoirs by the detailed study of the boreholes logs, to determine the different lithologies, show a good correlation between the good potential aquifer zones and the volcano-sedimentary filling basins. The marginal basins, the type II basins, and the pull-apart basins would have better characteristics by their lithology and on the other hand by their fracturing and porosity, to constitute good aquifers. However, the granitic zones are areas with low potential because of their resistance to weathering but also less affected by fractures. The integration of all these data shows a good correlation between areas with high aquifer potential and geological sedimentation basins. Indeed, the volcanosedimentary ones present the best potential aquifers and they constitute the formations of filling of the marginal basins and basins in pull-apart. The installation of these basins has led to sedimentation offering better fracturing and porosity, but a 
significant alteration contributing to a better recharge of aquifers.

\section{References}

[1] Wackermann. J. M., 1975, L'altération des massifs cristallins basiques en zone tropicale semi-humide. Études minéralogiques et géochimiques des arènes du Sénégal Oriental. Conséquences pour la cartographie et la prospection. Thèse, sciences Univ Louis Pasteur Strasbourg, 338 p.

[2] Blot A., 1980, L'altération climatique des massifs de granites du Sénégal. Thèse de Doctorat ès Sciences (1980) et mémoires ORSTOM n 114 , Paris 434 .

[3] Travi. Y., mudry. J., 1997, Méthode pour l'évaluation et la gestion du risque nitrate dans les aquifères de socle de la zone sahélienne d'Afrique de l'Ouest. Journal hydrogéologie, $n^{\circ} 1$, 13-21.

[4] Diouf. S. 1999, Hydrgéologie en zone de socle cristallin et cristallophyllien du Sénégal oriental. Application de la méthode électrique $1 \mathrm{D}$ et $2 \mathrm{D}$ à la localisation et à la caractérisation des aquifères du batholite de Saraya et ses environs. Thèse de doctorat de 3ecycle. Univ. C. A. D. de Dakar, $86 \mathrm{p}$.

[5] Mall. I., 2009, Contribution à l'étude hydrogéochimique des aquifères de socle: cas du Sénégal oriental. Mémoire D. E. A Ucad, $80 \mathrm{pp}$.

[6] Wuilleumier, A., Mall, I. et Ndiaye, P. M., 2010a, Carte hydrogéologique à 1/500 000 du Sénégal oriental. Ministère des Mines, de l'Industrie, de l'Agro-Industrie et des PME, Direction des Mines et de la Géologie, Dakar.

[7] Mall. I*, M. Diaw, H. D. Madioune, P. M. Ngom and S. Faye 2014, Use of Remote Sensing and GIS for Groundwater Potential Mapping in Crystalline Basement Rock (Sabodala Mining Region Senegal). Nova Science Publishers, Inc. https://www.novapublishers.com/catalog/index.php.

[8] Mall, I. (2017). Evaluation des ressources en eau dans le socle birrimien du Sénégal oriental: approts des outils geochimiquess, geostatistiques, de la Teledection et des SIG. Thèse de doctorat, Université Cheikh Anta Diop, 213 pages.

[9] SCANVIC J. Y., 1983, Utilisation de la télédétection dans les Sciences de la Terre. Ed. B. R. G. M.

[10] Biémi J. 1992, Contribution à l'étude géologique, hydrogéologique et par télédétection des bassins versants subsahéliens du socle précambrien d'Afrique de l'Ouest: Hydrostructurale, hydrodynamique, hydrochimie et isotopie des aquifères discontinus de sillons et aires granitiques de la haute Marahoué (Côte d'Ivoire). Thèse d'Etat, Univ. Abidjan, $480 \mathrm{p}$.

[11] Blom. R. G, Robert E. Crippen, C. E. 1984, Detection of subsurface features in SEASAT radar images of Means Valley, Mojave Desert, California. Geology; 12 (6): 346-349. doi: https://doi.org/10.1130/0091-

7613(1984)12<346:DOSFIS >2.0.CO;2.

[12] Gaddis. L. R. Mouginis-Mark P. J. Kaupp. V. H. 1989 Geologic analyses of Shuttle Imaging Radar (SIR-B) data of Kilauea Volcano, Hawaii. Published 1989 DOI: 10.1130/00167606(1989)101<0317:gaosir>2.3.co;2.
[13] YÉSOU H., 1993, Analyse d'image satellitaire radar et optique: optimisation et intégration des données. Apports à la géologie structurale et minière. Thèse Univ. Strasbourg, 232.

[14] Sisay L., 2007, Application of Remote Sensing and GIS for Groundwater Potential Zone Mapping in Northern. Ada'a Plain (Modjo Catchment). Addis Ababa University, Addis Ababa - 1176; 77 p.

[15] O'LEARY D. W., J. D. FRIEDMAN et H. A. POHN 1976. Lineaments, linear, lineations: some standards for old terms. Geol. Soc. Amer. Bull., 87, 1463-1469.

[16] Kouamé K. F., 1999, Hydrogéologie des régions de montagne: Apports des données de télédétection et des méthodes statistique et fractale à l'élaboration d'un système d'information hydrogéologique a référence spatiale des aquifères discontinus du secteur Man-Danané (ouest de la cote d'ivoire). Thèse de 3ème Cycle Université de Cocody.

[17] Rajasekhar M., Sudarsana Raju G.*, Bramaiah C., Deepthi P., Amaravathi Y., Sidd Raju R. 2019. Delineation of Groundwater Potential Zones of SemiArid Region of YSR Kadapa District, Andhra Pradesh, India using RS, GIS and Analytic Hierarchy Process. Remote Sensing of Land, 2 (2), 76-86, 2018. http://dx.doi.org/10.21523/gcj1.18020201.

[18] Diene, M. 2012. Evolution structural d'un segment du Craton Ouest Africain: Cas des formations paléoprotérozoïques du Supergroupe de Mako, Boutonnière de Kédougou-Kéniéba (Sud-Est du Sénégal). Thèse de Doctorat unique UCAD, 153 p.

[19] Mashael Al Saud 2010. Mapping potential areas for groundwater storage in Wadi Aurnah Basin, western Arabian Peninsula, using remote sensing and geographic information system techniques. Hydrogeology Journal (2010) 18: 14811495 DOI 10.1007/s10040-010-0598-9.

[20] Tejpal. M, Sitender. Dr; Ansha Ms. 2016. Delineation of groundwater potential zones using GIS and HP techniques in Tangri Watershed area of Harayana and Punjab, India. Journal of the Eastern Geographical society. Vol XXII, N${ }^{\circ}$. Pp 161172 .

[21] Theveniaut, H., Ndiaye, P. M., Buscail, F., Coueffe, R., Delor, C., Fullgraf, T. and Goujou, J. C. (2010) Notice explicative de la carte géologique du Sénégal oriental à 1/500 000. Ministère des Mines, de l'Industrie, de l'Agro-Industrie et des PME, Direction des Mines et de la Géologie, Dakar, 120 p.

[22] OMVS 2013. Actualisation de la monographie hydrologique du fleuve Sénégal. Rapport final, 700 pp.

[23] Diene, M., Gueye, M., Diallo, D. P. and Dia, A. 2012. Structural Evolution of a Precambrian Segment: Example of the Paleoproterozoic Formations of the Mako Belt (Eastern Senegal, West Africa). International Journal of Geosciences, 3, 153-165. http://dx.doi.org/10.4236/ijg.2012.31017.

[24] Kumar, B., Chandola1, K. V., Mohan, D. and Patra, K. C., 2015. A way to identify groundwater potential zones (GWPZS) in Rocky Terrains (India), Eco. Env. and Cons. 22 (3), 221-226.

[25] Mallick, J., Singh, C. K., Al-wadi, H., Ahmed, M., Rahman, A., Shashtri, S., and Mukherjee, S., 2014. Geospatial and geostatistical approach for groundwater potential zone delineation. Hydrological Process, 29 (3), 395-418. DOI: https://doi.org/10.1002/hyp.10153. 
[26] Shankar, M. N. R. and Mohan, G., 2005. A GIS based hydrogeomorphic approach for identification of sitespecific artificial-recharge techniques in the Deccan Volcanic Province. Journal of Earth System Science, 114 (5), 505-514. DOI: https://doi.org/10.1007/BF02702026.

[27] Mohammadi-Behzad. H. R; Charchi A.: Kalantari N.; Mehrabi Nejad A; Karimi Vardanjani. H. 2018. Delineation of groundwater potential zones using remote sensing (RS), geographical information system (GIS) and analytic hierarchy process (AHP) techniques: a case study in the Leylia-Keynow watershed, southwest of Iran. Springer-Verlag $\mathrm{GmbH}$ Germany, part of Springer Nature.

[28] Shekhar S, Pandey AC. 2014. Delineation of groundwater potential zone in hard rock terrain of India using remote sensing, geographical information system (GIS) and analytic hierarchy process (AHP) techniques. Geocarto Int 30 (4): 402-442.

[29] Chung CJF, Fabbri AG. 2003 Validation of spatial prediction models for landslide hazard mapping. Nat Hazards 30 (3): 451-472. 